Original article

\title{
Does dentifrice provide the necessary saturation of ions in oral fluids to favour remineralisation?
}

\author{
Pavel V. Seredin ${ }^{1}$, Dmitry L. Goloshchapov ${ }^{1}$, Yuri A. Ippolitov ${ }^{2}$, Edvard S. Kalivradzhiyan ${ }^{2}$ \\ ${ }^{1}$ Voronezh State University, Voronezh, Russia \\ ${ }^{2}$ Voronezh State Medical University n.a. N.N. Burdenko, Voronezh, Russia
}

Received 3 October 2017, Revised 15 December 2017, Accepted 24 December 2017

(C) 2017, Seredin P.V., Goloshchapov D.L., Ippolitov Yu.A., Kalivradzhiyan E.S.

(C) 2017, Russian Open Medical Journal

\begin{abstract}
Background - Changes in the molecular composition of mixed human saliva using endogenous and exogenous methods of caries prevention were studied and the duration of these changes in relation to the initial state of the oral fluid was determined.

Material and Methods - In total, 200 European healthy, addiction-free, university-educated males and females, aged 22-30 were recruited for the study. Participants collected their mixed saliva samples after the use of a multi-mineral toothpaste (exogenous prevention) and after three days of taking a calcium glycerophosphate tablet (endogenous prevention). In the first stage of the study, samples of mixed saliva were analysed by infrared (IR) lab spectrometer and equipment of infrared microspectroscopy beamline at the Australian Synchrotron (Victoria, Australia) was used in the second stage of study.

Results - Based on the experimental data obtained by IR-spectroscopy technique, the mineral/organic and carbon/phosphate ratios were calculated. The changes in the organic mineral balance of the oral cavity induced by these two preventive methods were analysed. The statistical significance of the results for the confidence level of $p$ is indicated. The data shows that changes in the molecular composition of mixed saliva when using an exogenous method of caries prevention only provides a short-term effect, continuing for the first 30 minutes after the preceding prevention. Moreover, calcium glycerophosphate tablets can change the organic-mineral balance in mixed saliva, increasing the content of mineral groups and complexes. The content of endogenous, biologically accessible phosphate groups and complexes in the mixed saliva exceeds by approximately $12 \%$ that of the mixed saliva before the use of the prevention agents.

Conclusion - Use of calcium glycerophosphate tablets in combination with brushing (a combination of endogenous and exogenous prevention methods) leads to the long-term presence of high concentrations of ions, mineral complexes and groups (phosphates) in the oral fluid.
\end{abstract}

Keywords: mixed saliva, molecular composition, IR-spectroscopy, caries prophylaxis

Cite as Seredin PV, Goloshchapov DL, Ippolitov YuA, Kalivradzhiyan ES. Does dentifrice provide the necessary saturation of ions in oral fluids to favour remineralisation? Russian Open Medical Journal 2018; 7: e0106.

Correspondence to Pavel V. Seredin. Address: Department of Solid State Physics and Nanostructures, Voronezh State University, University sq. 1, Voronezh, 394006, Russia. E-mail: paul@phys.vsu.ru. Phone: +7 4732208363.

\section{Introduction}

It is well-known that hygienic methods for oral cavity care and caries prevention induce changes in the molecular composition of fluids within the oral cavity, thereby affecting teeth health [1-3]. The significance of the changes in the molecular composition of mixed saliva has been previously shown in diabetes, oncology and pathologies of the oral cavity [4-9]. Considerable deviation of the molecular composition in the oral fluid can have an influence on the content of mineral complexes in plaque fluid and thus, impact on the process of enamel remineralisation [1, 10-13]. Remineralisation is the recognised process of dental enamel recovery promoted by the plaque fluid and mixed saliva being oversaturated with ions $\left(\mathrm{Ca}^{2+}, \mathrm{HPO}_{4}{ }^{2-}, \mathrm{Na}^{+}, \mathrm{Mg}^{2+}, \mathrm{Cl}^{-}, \mathrm{F}^{-}, \mathrm{OH}^{-}\right.$, etc.) relative to the composition of dental enamel $[12,14]$. Therefore, the change of concentration for both organic and inorganic substances in the oral fluid results in a decrease in the gradient relative to dental biofilm, impacting on the state of the dental enamel health [15-18]. Consequently, studies of the impact of exogenous and endogenous preventive drugs on the change in the molecular composition of the oral fluid are relevant.

The investigation and comparison of different prevention methods, including fluoridation, will determine which phosphorusand calcium-containing agents promote the recovery of dental enamel [11, 15, 19-23]. The prophylactic efficiency of exogenous methods, namely tooth brushing, gel application and laser irradiation, has been demonstrated [20, 21, 24-28]. However, such exogenous methods do not promote the balance between the natural processes of mineral loss and their replacement in the plaque fluid and mixed saliva [29]. The development of some tooth lesions is a long-term process and in cases where the concentration of the necessary mineral and organic sources is reduced, the factors resulting in demineralisation will dominate. These processes prove to be a consequence of the changes in mineral-organic of the plaque fluid and mixed saliva. However, the molecular composition of these substances can be altered due to the intake of special preventive drugs (endogenous prophylaxis) on 
the basis of calcium phosphates $[16,17,20,30,31]$, in particular, the endogenous prophylactic calcium glycerophosphate [32-35]. The use of such preventive drugs can achieve optimal concentrations of calcium and phosphate in mixed human saliva, however, possible changes in composition have not been considered. Moreover, there is no information in literature regarding the comparative analysis of changes in the mixed saliva molecular composition when using different caries preventive drugs since this issue requires an interdisciplinary approach. The significance of this information for explaining the processes proceeding at the tentative boundary between plaque fluid and mixed saliva is indisputable, as confirmed by a number of investigations $[6,8,29,30]$. Therefore, the aim of this study is to investigate the changes in the molecular composition of human mixed saliva with the use of endogenous and exogenous methods for caries prevention and to determine the duration of these changes in relation to the initial state of the oral fluid.

\section{Material and Methods}

\section{Study population}

Two hundred healthy, addiction-free, university-educated participants ( 100 men and 100 women) aged 22-30 were recruited via the website of Voronezh State Medical University n.a. N.N. Burdenko (Voronezh, Russia). Informed consent was obtained from all participants and they all provided their own mixed saliva for the investigations. All participants collected their samples at the dental lab.

\section{Mixed saliva sampling}

It should be noted that this study investigated mixed saliva with the composition being different from that of a mix of salivary glands. For exogenous and endogenous prevention, there will be derivatives of the prevention substances in the mixed saliva which will enter through the oral cavity (a toothpaste) or salivary glands (use of a mineral complex based on calcium glycerophosphate). All procedures concerning the collection of mixed saliva samples were performed in laboratory conditions, with participants invited to the laboratory in groups of 20 for salvia collection.

Mixed saliva sampling was implemented as follows: in the week prior to, and during sampling, the participants mainly ate vegetables, followed a standard water consumption pattern (recommended daily water consumption was 1.0-1.5 I, without the use of mineralized or preconditioned water) and they not take any remedies or alcohol. The collection of mixed saliva was repeated twice, without any stimulation and all samples were collected into sterile $15 \mathrm{ml}$ tube. In the first stage of the study, mixed saliva was sampled on the eighth day after the beginning of the observations (without any changes in conditions of the oral cavity hygiene in the morning just before eating), after preliminary oral rinsing. This mixed saliva was used as a reference sample.

In order to explore the changes in the molecular composition of human mixed saliva when using an exogenous method of prevention, a pea-sized amount of toothpaste with a multi-mineral complex was used in combination with a calcium glycerophosphate tablet. On the same day, the participants applied toothpaste for brushing after collection of the reference sample and collected the mixed saliva sample 5 minutes after that. A third sample was collected 30 minutes later. The next day, the participants began to take the tablets (a pelleted mineral complex of calcium glycerophosphate), one tablet three times a day after food intake. Three days after that, when the first pellet was taken in the morning, food intake, and after oral rinsing, mixed saliva was sampled once again.

During the second stage of experiment the following regulations were specified for mixed saliva sampling. Similar to the first stage of the experiment, seven days later (after the beginning of this second stage without the changes of conditions for hygienic measures of the oral cavity), in the morning before eating, participants of the experiment sampled their own mixed saliva for the first time after oral rinsing. On the same day, after sampling the mixed saliva, the participants used the same toothpaste for teeth brushing. Five minutes later, after proceeding with the hygienic measures for the oral cavity with the use of toothpaste and a thorough oral rinsing, mixed saliva was sampled once again. Thirty minutes later after a thorough oral rinsing, the mixed saliva was sampled for the third time. The next day, participants began to take the calcium glycerophosphate tablets, one tablet three times a day. Three days after that in the morning, on an empty stomach, the patients thoroughly carried out oral rinsing and they were again subjected to mixed saliva sampling.

\section{Sample preparation}

The mixed saliva was collected into a sterile container, immediately centrifuged at the dental lab and dried at $36^{\circ} \mathrm{C}$ in a desiccator to remove excess water. Sample biospecimen description data, in accordance with the Biospecimen Reporting for Improved Study Quality (BRISQ) recommendations, are presented in Table 1.

\section{Infrared microspectroscopy analysis}

Mixed saliva samples were analysed by infrared (IR) spectroscopy, a highly selective and sensitive method allowing extensive information on the structure of substances, the effect of atomic groups comprising compounds, as well as the detection of neogenic organic and mineral phases [5, 9, 36-38]. It can also be used to analyse multi-component compounds. For the first stage of the study, Vertex-70 (Bruker, Germany) was applied to a survey of IR spectra and an attachment for the attenuated total reflection (ATR) spectroscopy (PLATINUM ATR, Bruker, Germany) with a diamond prism. IR spectra were surveyed in the range of 4000 $500 \mathrm{~cm}^{-1}$.

Table 1. Biospecimen description in accordance with the Biospecimen Reporting for Improved Study Quality (BRISQ) recommendations

\begin{tabular}{ll}
\hline Data elements & \multicolumn{1}{c}{ Objects and properties } \\
\hline Biospecimen type & Mixed saliva \\
Anatomical site & Mixed saliva \\
Disease status of patients & Healthy \\
Clinical characteristics of patients & $\begin{array}{l}\text { Patients who regularly maintain } \\
\text { oral hygiene, without pernicious } \\
\text { habits }\end{array}$ \\
& Alive \\
Vital state of patients & Direct collection of the saliva \\
Collection mechanism & Air-tight container \\
Type of stabilisation & Drying in the air $\left(36.6^{\circ} \mathrm{C}\right)$ \\
Type of long-term preservation & Air-tight container \\
Constitution of preservative & 20 to $25^{\circ} \mathrm{C}$ \\
Storage temperature & 4 and 7 days (for the first and \\
Storage duration & second experiment, respectively) \\
Shipping temperature & $20^{\circ} \mathrm{C}$ to $25^{\circ} \mathrm{C}$ \\
\hline
\end{tabular}




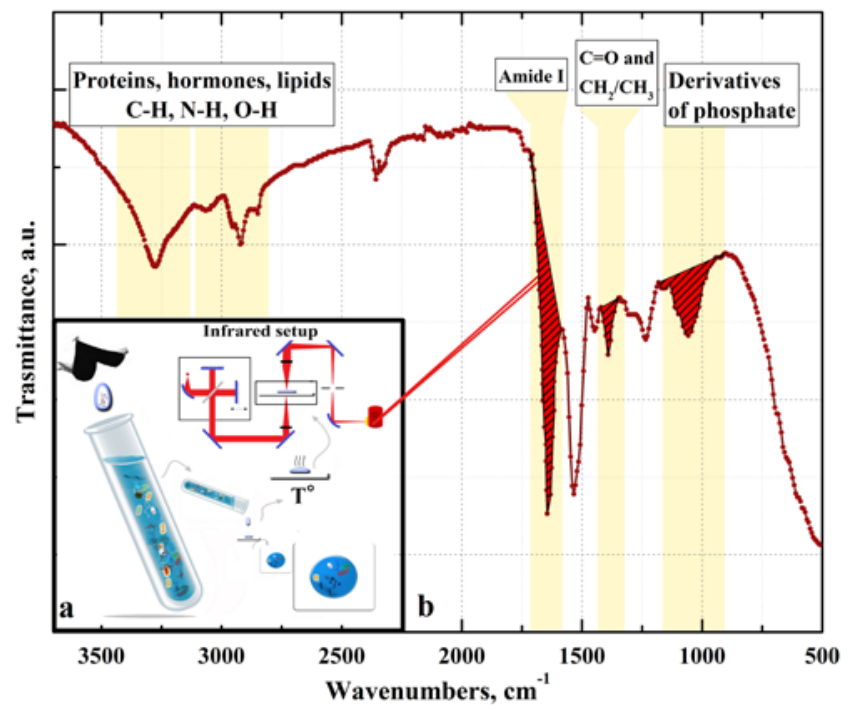

Figure 1. Design of experiment to study of mixed saliva samples with use of IR-spectroscopy.

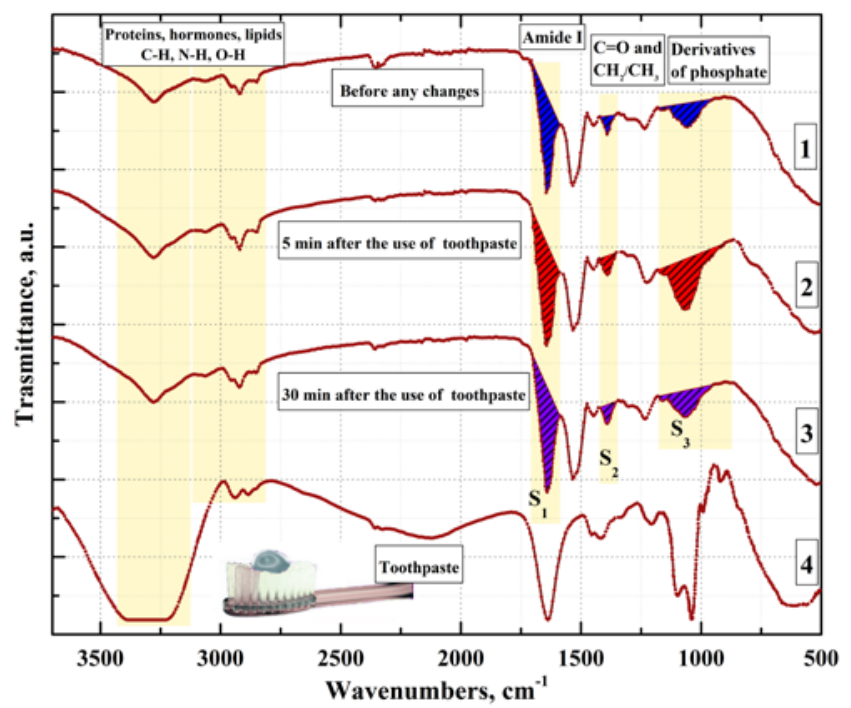

Figure 2. IR transmission spectra, obtained with the use of ATR attachment with a diamond prism, of the mixed saliva taken before and after the use of multi-mineral toothpaste at the first stage of the study. 1 - IR spectrum of the reference mixed saliva sample, 2 - spectrum of mixed saliva taken five minutes after use of multi-mineral complex toothpaste, $\mathbf{3}$ - spectrum of the mixed saliva taken $\mathbf{3 0}$ minutes after the use of toothpaste, 4 - spectrum of the multi-mineral complex toothpaste.

For the second stage of the study, an IR microspectroscopy technique utilising the equipment of the infrared microspectroscopy (IRM) beamline at Australian Synchrotron (Victoria, Australia) was used. A Bruker V80v Fourier Transform Infrared (FTIR) spectrometer and a Hyperion 3000 IR microscope (Bruker, Germany) were used to perform the analysis of a microprobe of the specimens as well as a diamond high-pressure cell. Transmission IR spectra were measured within the range of 4000-500 $\mathrm{cm}^{-1}$.

Figure 1 shows a diagram detailing the experimental design, i.e. how the use of the IR spectroscopy method allows the study of samples of mixed saliva. As noted in [36], the use of any medications is revealed in the molecular spectra of mixed saliva as also confirmed in $[39,40]$. Hence, the application of IRspectroscopy for the analysis of the changes in the molecular composition of the oral fluid is a logical and tested approach demonstrating high-precision results $[4,5,41,36]$. All the vibration mods of the samples were signed in accordance of the reference sources of IR spectroscopy [5, 38, 41-45] and tabulated in Table 2.

Spectra collection, plotting, manipulation with spectra, their normalisation and averaging, and evaluation and integration of spectra and all data calculations were performed using the professional Bruker Optics software OPUS (versions 7.2 and 7.5). Final conversion from OPUS figure pdf format to figure (600 dpi) jpg format and inscriptions in figures were made using CorelDRAW Graphics Suite X7.

\section{Statistical analysis}

Statistical analysis of the changes in mineral-organic and carbon-phosphate ratios in the dry residues of mixed saliva for the groups of patients was performed with the use of the professional software for the statistical analysis SPSS v.19 for Windows (SPSS Inc., Chicago, Illinois, USA). Statistical analysis was conducted at the statistical significance level of $p<0.05, n=200$. To find statistical significant differences in experimental data t-tests have been used after Shapiro-Wilk test to check normal distribution in sampling. The results in Table 3 and in Figures 5-6 are presented as a mean with standard deviation $(\mathrm{M} \pm \mathrm{SD})$, and the $p$-level of statistical significance of the results is also indicated.

\section{Results}

The IR transmission spectra of mixed saliva collected at the different stages of the study (according to the described regulations) were obtained for all the participants and are presented in Figures 2-5. As seen from these figures, the application of synchrotron radiation in the second stage of the study for the analysis of samples (together with the IR microscope) compared with the technique used in the first stage made it possible to obtain IR transmission spectra of the samples, providing a better signal-to-noise ratio and better resolution.

The primary analysis of the experimental data demonstrated that all of the obtained spectra included the same set of vibration modes and were only slightly different in the intensities of certain vibration modes. It should be noted that IR spectra obtained in the second stage revealed more information on the qualitative composition of the samples due to the specific features of their excitation. Taking this in account, only normalised IR transmission spectra of the mixed saliva were averaged over the group of patients participating in the experiment (as presented in Figures 2-5).

IR transmission spectra obtained with the use of synchrotron radiation and a high-pressure attachment with a diamond prism to an IR microscope are given in Figures 4-5.

The analysis of the obtained IR spectra was performed based on a number of data taken from a set of reference sources, where human mixed saliva and hard dental tissues, as well as phosphates related to the formation of dentin and enamel were investigated by means of IR spectroscopy [5, 38, 41-45]. A list of the active vibrations in the spectra of the first and second stages of the study, the ranges, and the frequencies with the peaks of vibration bands are presented in Table 1 along with their assignments to the groups of vibrations. 
Table 2. Active vibrations bands in the IR-spectra at the first and second stages of the experiments and reference data

\begin{tabular}{|c|c|c|c|c|c|}
\hline \multirow[t]{2}{*}{ Substance } & \multirow[t]{2}{*}{ Vibration modes } & \multirow[t]{2}{*}{ Wavenumbers, $\mathrm{cm}^{-1}$} & \multicolumn{2}{|c|}{ Experiment } & \multirow[t]{2}{*}{ Refs } \\
\hline & & & Exp.1 & Exp.2 & \\
\hline \multirow[t]{3}{*}{ Proteins } & Amide VI Out-of-plane $\mathrm{C}=\mathrm{O}$ bending of proteins & $537-606$ & & + & 40,44 \\
\hline & Amide V Out-of-plane NH bending of proteins & $625-767$ & & + & 40,44 \\
\hline & Amide IV OCN bending of proteins & & & & \\
\hline \multirow[t]{5}{*}{ Phosphates } & $\mathrm{P}-\mathrm{O}$ band of $\mathrm{P}_{2} \mathrm{O}_{7}$ & $730-770$ & + & + & 45 \\
\hline & Oligo-\& polysaccharides, glycosilated proteins and phosphorus derivatives & $1025-1078$ & + & + & 41 \\
\hline & Mono and oligosaccharides & 1029 & + & + & 41 \\
\hline & Derivative of phosphate, glycerophosphate and phosphata & 1054 & + & + & 41 \\
\hline & Phospholipids, $\mathrm{C}-\mathrm{O}-\mathrm{P}-\mathrm{O}-\mathrm{C}$ vibrations & & & & \\
\hline \multirow{7}{*}{$\begin{array}{l}\text {-Proteins ( } \alpha- \\
\text { Amylase, Albumi } \\
\text { Cystatins, Mucin } \\
\text { Proline-rich } \\
\text { proteins, slgA) } \\
\text { - Hormones } \\
\text { (Cortisol, } \\
\text { Testosterone) }\end{array}$} & $\begin{array}{l}\mathrm{P}=\mathrm{O} \text { stretching (asymmetric) of }>\mathrm{PO}_{2}-\text { phosphodiesters stretching vibrations } \\
\text { of } \mathrm{C}=\mathrm{O} \text { groups (Amide I) }\end{array}$ & $1240-1244$ & + & + & $5,38,41$ \\
\hline & Amide III (CN stretching, NH bending) band components of proteins & 1272 & & + & 5 \\
\hline & Amide III (CN stretching, NH bending) band components of proteins & 1316 & + & & 5 \\
\hline & Stretch - carboxyl group vCOO & $1330-1345$ & & + & 5,41 \\
\hline & Amide II (CN stretching, NH bending) & 1378 & + & & 5 \\
\hline & $\mathrm{C}=\mathrm{O}$ stretching (symmetric) of $\mathrm{COO}^{-}$ & 1401 & + & + & 5 \\
\hline & $\mathrm{CH}_{2} / \mathrm{CH}_{3}$ & $1397-1410,1452$ & + & + & $5,38,41$ \\
\hline \multirow{14}{*}{$\begin{array}{l}\text { - Proteins ( } \alpha- \\
\text { Amylase, Albumin, } \\
\text { Cystatins, Mucins, } \\
\text { Proline-rich } \\
\text { proteins; slgA) }\end{array}$} & Tyrosineb and N-H (amide II), $\alpha$-helix: proteins, amino acids & 1516 & & & 5 \\
\hline & Amide II (CN stretching, NH bending) & $1548-1553$ & \pm & + & $5,38,41$ \\
\hline & $\begin{array}{l}(\mathrm{HNH})\left(\mathrm{NH}_{2}\right) \text { Amide II (CN stretching, } \mathrm{NH} \text { bending vibrations) (aminoacids, } \\
\text { peptides, protein) }\end{array}$ & 1570 & + & + & 5,41 \\
\hline & $\mathrm{N}-\mathrm{H}$ (amide II), $\alpha$-helix: proteins, amino acids & 1594 & & & 5 \\
\hline & Amide $\mathrm{I}(\mathrm{C}=\mathrm{O}$ stretching $)$ of $\beta$-pleated sheet structures & 1621 & & & 5 \\
\hline & Amide I ( $\mathrm{C}=0$ stretching) of $\beta$-pleated sheet structures & 1634 & & & 5 \\
\hline & Amide I ( $\mathrm{C}=\mathrm{O}$ stretching) of $\beta$-pleated sheet structures & $1645-1650$ & + & + & $5,38,41$ \\
\hline & Amide I ( $\mathrm{C}=\mathrm{O}$ stretching) and (COO-) stretching vibration & & & & \\
\hline & Amide I of $\alpha$-helical structures & 1658 & & & 5 \\
\hline & Amide I $(C=0$ stretching) of $\alpha$-helical structures & 1659 & & & 5 \\
\hline & $\begin{array}{l}\text { Amide I }(\mathrm{C}=0 \text { stretching) band components resulting from antiparallel } \\
\text { pleated sheets and } \beta \text {-turns of proteins }\end{array}$ & 1675 & & & 5 \\
\hline & $\mathrm{C}-\mathrm{H}$ stretching (symmetric) of $>\mathrm{CH}_{2}$ in fatty acids & 2852 & + & & 5,38 \\
\hline & $\begin{array}{l}\text { Stretching vibrations of SCN, unique to saliva, converted by salivary } \\
\text { peroxidases to hypothiocyanate, a local antibacterial age }\end{array}$ & $2137-2140$ & + & + & 41 \\
\hline & Stretching vibrations of $\mathrm{CH}$ - links of lipid molecules & $2280-2380$ & & + & 41 \\
\hline \multirow{5}{*}{$\begin{array}{l}\text {-Lipids (cholesterol } \\
\text { and } \\
\text { mono/diglycerides } \\
\text { of fatty acids) }\end{array}$} & $\mathrm{C}-\mathrm{H}$ stretching (symmetric) of $-\mathrm{CH}_{3}$ & 2875 & & + & 5 \\
\hline & $\mathrm{C}-\mathrm{H}$ stretching of $\mathrm{C}-\mathrm{H}$ in methine groups & 2899 & & & 5 \\
\hline & $\mathrm{C}-\mathrm{H}$ stretching of $\mathrm{C}-\mathrm{H}$ & 2916 & & & 5 \\
\hline & $\mathrm{C}-\mathrm{H}$ stretching (symmetric) of $>\mathrm{CH}_{2}$ in fatty acids & 2925 & + & + & 5,38 \\
\hline & $\mathrm{C}-\mathrm{H}$ stretching (symmetric) of $>\mathrm{CH}_{2}$ in fatty acids & 2964 & \pm & + & 5 \\
\hline \multirow{5}{*}{$\begin{array}{l}\text { - Proteins ( } \alpha \text { - } \\
\text { Amylase, Albumin, } \\
\text { Cystatins, Mucins, } \\
\text { Proline-rich } \\
\text { proteins, slgA) }\end{array}$} & Primary and secondary amines $\left(\mathrm{H}_{2}\right.$ and $\left.\mathrm{NHR}\right)$ & 3067 & \pm & \pm & 5 \\
\hline & $\mathrm{N}-\mathrm{H}$ stretching (Amide A) of proteins & 3130 & & & 5 \\
\hline & $\mathrm{N}-\mathrm{H}$ stretching (amide $\mathrm{A}$ ) of proteins & 3204 & + & + & 5 \\
\hline & $\mathrm{N}-\mathrm{H}$ stretching (amide $\mathrm{A}$ ) of proteins & $3290-3293$ & + & + & 38,41 \\
\hline & $\mathrm{N}-\mathrm{H}$ stretching (amide $\mathrm{A}$ ) of proteins & 3349 & & & 5 \\
\hline \multirow{3}{*}{$\begin{array}{l}\text { - Hormones } \\
\text { (Cortisol, } \\
\text { Testosterone) }\end{array}$} & $(\mathrm{NH})\left(\mathrm{NH}_{2}\right)$ asymmetric vibrations & 3411 & & & 5 \\
\hline & O-H stretching of hydroxyl groups & 3437 & & & 5 \\
\hline & $\mathrm{O}-\mathrm{H}$ stretching of hydroxyl groups & 3461 & & & 5 \\
\hline
\end{tabular}

From the obtained experimental data (Figures 2-5, Table 2), it follows that the main vibration bands in the IR transmission spectra of all the mixed saliva samples from the first and second stages of the study can be assigned to the following groups and complexes. The first and most interesting group of high-intensity vibrations arranged in all spectra within $900-1200 \mathrm{~cm}^{-1}$ is related to the modes, and their appearance is connected with the presence of phosphorus derivatives in the samples, such as phosphates, glycerophosphates and phospholipids [38, 40]. The observed similarity of blood and saliva spectra concerning the modes arranged at the value of 1050 $\mathrm{cm}^{-1}$ indicates that these vibrations are due to the organic derivatives of phosphates, glycerophosphates and phosphatase, namely to the $\mathrm{C}-\mathrm{O}-\mathrm{P}-\mathrm{O}-\mathrm{C}$ complex (Table 2).
The subsequent large group of vibration bands localised in the range of $1240-1700 \mathrm{~cm}^{-1}$ can be related to the secondary amides: Amide I $\left(80 \% \mathrm{C}=0\right.$ stretch in the range of $\left.1615-1675 \mathrm{~cm}^{-1}\right)$, Amide II $(60 \% \mathrm{~N}-\mathrm{H}$ bend and $40 \% \mathrm{C}-\mathrm{N}$ stretch in the range of $1520-1575 \mathrm{~cm}$ ${ }^{1}$ ) and Amide III (40\% C-N stretch and $30 \% \mathrm{~N}-\mathrm{H}$ bend in the range of $\left.1270-1315 \mathrm{~cm}^{-1}\right)$. Modes arranged in the experimental spectra in the range of $1400-1430 \mathrm{~cm}^{-1}$ belong to $\mathrm{C}=\mathrm{O}$ stretch (symmetric) vibrations of $\mathrm{COO}$ and $\mathrm{CH}_{2} / \mathrm{CH}_{3}$ groups (Table 2).

A group of bands in the IR spectra, localised in the range of $2750-2950 \mathrm{~cm}^{-1}$, correspond to vibrations of $\mathrm{C}-\mathrm{H}$ bonds. A broad vibration band within the range of $3250-3450 \mathrm{~cm}^{-1}$ is related to $\mathrm{N}-\mathrm{H}$ bonds of proteins and hormones. It can also be connected with the presence of $\mathrm{O}-\mathrm{H}$ hydroxyl groups (i.e. water) in the samples. 


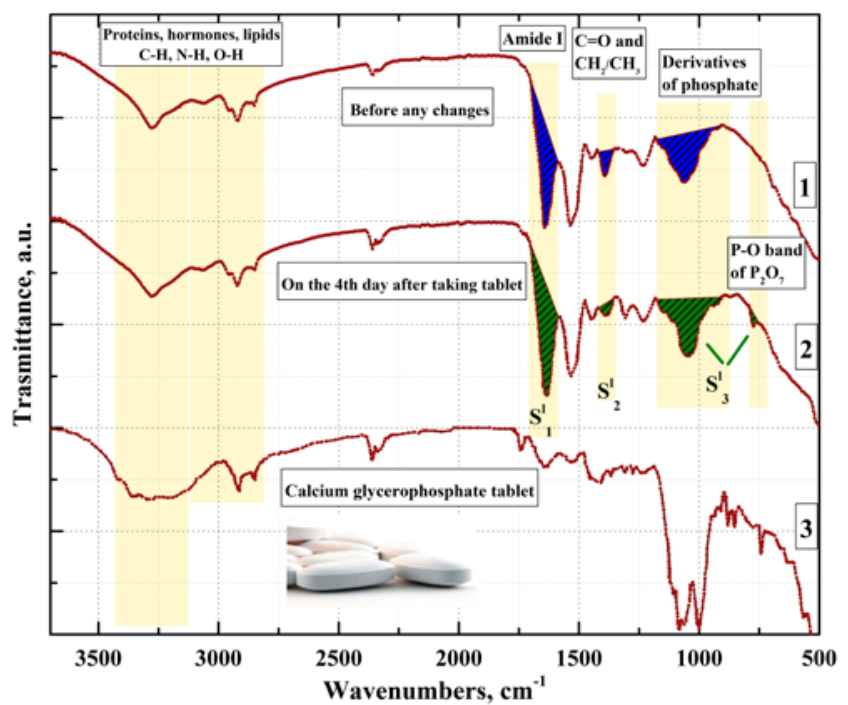

Figure 3. IR transmission spectra obtained with the use of ATR attachment with a diamond prism, of the mixed saliva sampled before and after intake of calcium glycerophosphate tablets in the first stage of the study. 1 - IR-spectrum of the mixed saliva reference sample, 2 - IRspectrum of the mixed saliva taken on the fourth day after taking the calcium glycerophosphate for three days, 3 - spectrum of a calcium glycerophosphate tablet

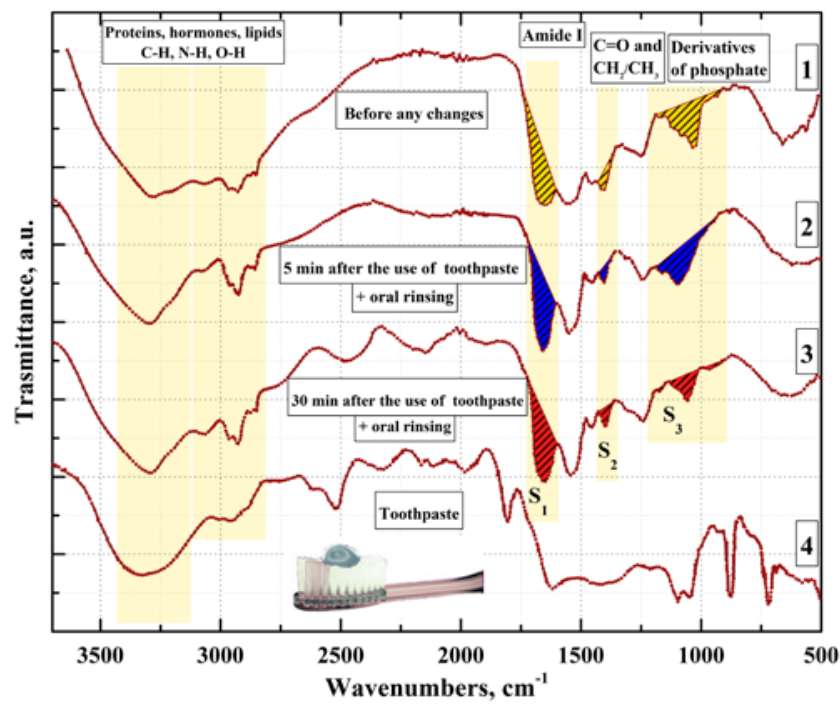

Figure 4. IR transmission spectra obtained with the use of synchrotron radiation and high-pressure attachment with a diamond prism to IR microscope of the mixed saliva taken before and after the use of multimineral complex toothpaste in the second stage of the study. 1- IRspectrum of the mixed saliva reference sample, 2 - spectrum of the mixed saliva taken five minutes after the use of toothpaste and a thorough oral rinsing, $\mathbf{3}$ - spectrum of the mixed saliva taken $\mathbf{3 0}$ minutes after the use of toothpaste and a thorough oral rinsing, 4 - spectrum of the multi-mineral complex toothpaste.

Moreover, in the IR absorption spectra of the mixed saliva, obtained with the use of synchrotron radiation (Figures 3 and 4), certain vibration bands were observed that can be associated with the appearance of $\mathrm{OCN}$ (Amide IV), $\mathrm{NH}$ (Amide $\mathrm{V}$ ) and $\mathrm{C}=\mathrm{O}$ (Amide $\mathrm{VI}$ ) vibrations of proteins arranged at $500-700 \mathrm{~cm}^{-1}$.

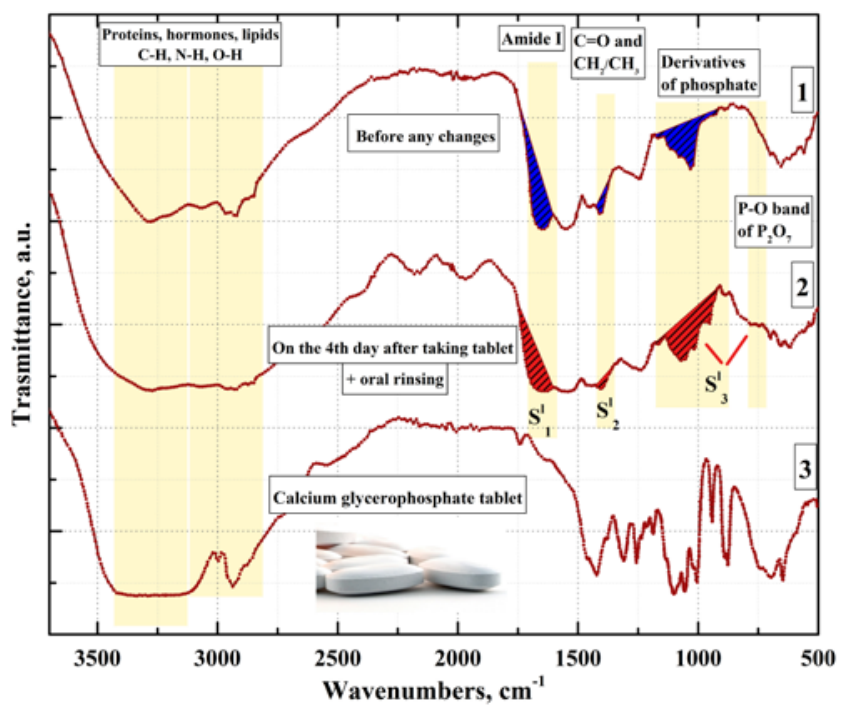

Figure 5. IR transmission spectra obtained with the use of synchrotron radiation and high-pressure attachment with a diamond prism to IR microscope of the mixed saliva taken before and after intake of calcium glycerophosphate tablets in the second stage of the study. 1 - IRspectrum of the mixed saliva reference sample, 2 - IR-spectrum of the mixed saliva taken on the fourth day after three days tablet taking and a thorough oral rinsing, 3 - spectrum of the calcium glycerophosphate tablet.

One should note that in the IR spectra of the mixed saliva collected on the fourth day, after three days of taking tablets and the spectrum of the calcium glycerophosphate, there is one more additional group of vibrations with a peak in the range of 730$770 \mathrm{~cm}^{-1}$. In the spectra obtained with the use of synchrotron radiation, two vibrations can be well resolved within the indicated spectral range, while in the spectra obtained with the use of an ATR attachment with the diamond prism, only one mode is observed for the samples from the first stage. This is the result of the better resolution for low-intensity vibration bands provided by the use of synchrotron radiation and methods of IR spectromicroscopy. It is necessary to emphasise that the appearance of these vibrations, their intensity and spectral position are identical for IR spectra from the first and second stages of the study. This fact is indicative of the complete correlation of IR spectroscopy data, independent of the method of excitation of IR radiation, as well as of the reproducibility of the experimental data.

There are no vibrations in the above mentioned range of IRspectrum before proceeding with the endogenous prophylaxis or exogenous prophylaxis. Based on the principles previously described [43], it seems impossible to correlate a group of vibrations characterised by the maxima at $730-770 \mathrm{~cm}^{-1}$ with the vibrations of $\mathrm{C}-\mathrm{H}$ bonds. However, this vibration mode can be related to the vibrations of the $\mathrm{P}-\mathrm{O}$ bond in the $\mathrm{P}_{2} \mathrm{O}_{7}$ group as a result of decomposition of the inorganic phosphate complexes. Indeed, these vibration modes have been observed under thermal decomposition of inorganic compounds [45].

Figures 2-5 represent IR spectra of the mixed saliva samples (together with the transmission spectra of multi-mineral complex toothpaste) on the basis of calcium glycerophosphate and IR spectra of the tablet on the basis of the mineral complex and a calcium glycerophosphate. The analysis of the experimental data 
and their comparison with the spectra of the mixed saliva demonstrated that in the IR spectra of the preventive agents, one can see the groups of vibrations identical to those observed in the spectra of mixed salivas. It is due to the presence of similar organic-mineral groups and complexes in the composition of these preventive agents. Thus, application of the chosen preventive agents must be revealed in the changes of an organic-mineral balance of the mixed saliva and it can be observed in the IR spectra of the investigated samples.

Based on the proposed assumptions and using IR spectroscopy data, the above-named changes in the organic-mineral balance can be explored by the calculations and analysis of mineral-organic and carbon-phosphate ratios between the mineral and organic components in the mixed saliva. To calculate the first ratio it is sufficient to consider the ratio of the integral area $\left(S_{3}, S_{3}{ }_{3}\right)$ in the IR spectra (spectral regions at $900-1200 \mathrm{~cm}^{-1}$ and $730-770 \mathrm{~cm}^{-1}$ ) to the integral area $\left(\mathrm{S}_{1}, \mathrm{~S}_{1}^{\prime}\right)$ of vibration band $1615-1775 \mathrm{~cm}^{-1}$, related to Amide I (Figures 2-5, $\delta\left(S_{3} / S_{1}\right), \delta\left(S_{3}{ }_{3} / S^{\prime}{ }_{1}\right)$ ). The carbonphosphate ratio can be calculated from the ratio of integral area $\left(\mathrm{S}_{2}, \mathrm{~S}_{2}\right)$ of vibration bands for $\mathrm{C}=\mathrm{O}$ and $\mathrm{CH}_{2} / \mathrm{CH}_{3}$ bonds, localised in the range of $1430-1400 \mathrm{~cm}^{-1}$, to the integral area $\left(S_{3}, S^{\prime}{ }_{3}\right)$ of phosphate bands in the IR spectrum $\left(900-1200 \mathrm{~cm}^{-1}\right.$ and $730-$ $770 \mathrm{~cm}^{-1}$ ) (Figures 2-5, $\delta\left(S_{2} / S_{3}\right), \delta\left(S_{2}^{\prime} / S^{\prime}{ }_{3}\right)$ ). Calculations of these ratios were performed with the use of the software OPUS (Bruker), including a wide set of functional facilities for different types of measurements, data treatment and evaluation obtained by IR spectroscopy. The results of quantitative calculations of relative changes in mineral-organic and carbon-phosphate ratios between the mineral and organic components in the mixed saliva in comparison of the reference sample at the different stages of the experiment are presented in Table 3 and in the Figures 6 and 7. It should be noted these ratios are averaged over the groups of participants taking part in the investigations for the different stages of the study and are presented as a mean \pm standard deviation.

\section{Discussion}

Our approach is based on the mathematical estimation of the changes in mineral-organic and carbon-phosphate ratios for human mixed saliva before and after the use of exo- and endogenous drug prevention based on the experimental data obtained by IR-spectroscopy. The use of IR-spectroscopy is appropriate due to its high precision, non-invasive character, clarity and selectivity, especially in dental research [38, 41-46].

The qualitative evaluation of changes in the mineral-organic $\delta_{1}\left(S_{3} / S_{1}\right), \delta_{2}\left(S_{3} / S_{1}\right), \delta_{3}\left(S^{\prime}{ }_{3} / S^{\prime}{ }_{1}\right)$ (Figure 6) and carbon-phosphate $\delta_{1}\left(S_{2} / S_{3}\right), \delta_{2}\left(S_{2} / S_{3}\right), \delta_{3}\left(S_{2}{ }_{2} / S_{3}^{\prime}\right)$ (Figure 7) ratios were deduced from mixed saliva composition (Table 3 ). It is well known that the oral cavity contains mixed saliva with a composition different from that of a mix of gland fluids $[1,8,47]$. For exogenous and endogenous prevention, there will also be derivatives of the preventive measures which enter the mixed saliva, either through the oral cavity (toothpaste) or through the gland fluids (use of a mineral complex of calcium glycerophosphate). Hence, based on changes occurring in the composition of the mixed saliva at different stages of prevention, one can evaluate their efficiency for long-term maintenance of the mineral and organic composition of the mixed saliva to compensate for mineral loss. Obvious changes in carbon/phosphate and mineral/organic ratios can be observed at the different experimental stages as shown in Figures 6-7.

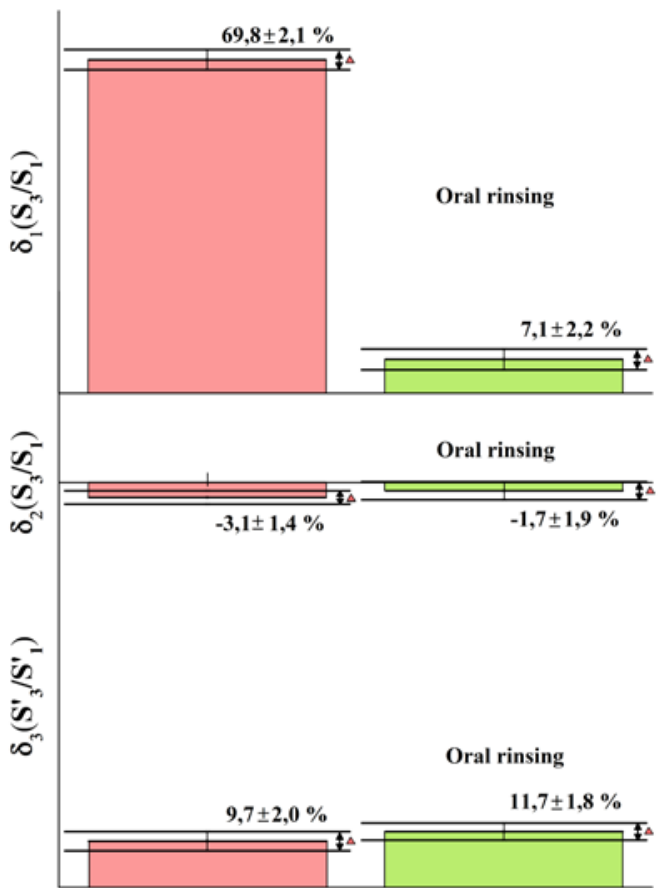

Figure 6. Relative changes in mineral-organic ratios at the first and the second stages of the study. $\delta_{1}\left(S_{3} / S_{1}\right)-5 \mathrm{~min}$ after the use of multimineral complex toothpaste; $\delta_{2}\left(S_{3} / S_{1}\right)-30 \mathrm{~min}$ after the use of multimineral complex toothpaste; $\delta_{3}\left(S_{3}^{\prime} / S^{\prime}{ }_{1}\right)$ - use of calcium glycerophosphate tablets. $S_{3}, S_{3}^{\prime}$ - the integral area of phosphates in the IR spectra (spectral regions at 900-1200 cm and 730-770 $\mathrm{cm}^{-1}$ ); $\mathrm{S}_{1}, \mathrm{~S}^{\prime}{ }_{1}-$ the integral area of vibration band $1615-1775 \mathrm{~cm}^{-1}$, related to Amide $\mathrm{I}$.

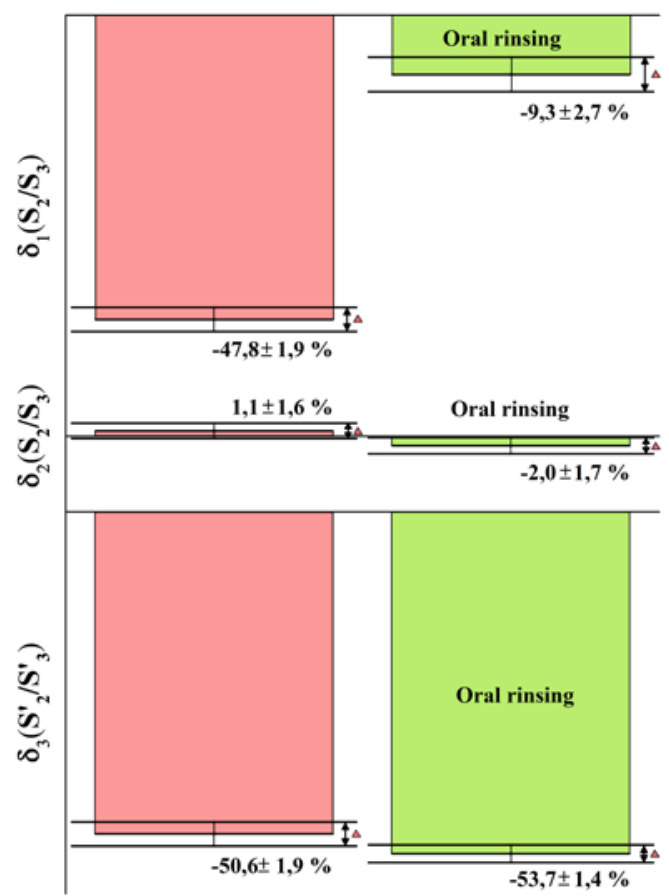

Figure 7. Relative changes in carbon-phosphate ratios at the first and the second stages of the study. $\delta_{1}\left(S_{2} / S_{3}\right)-5 \mathrm{~min}$ after the use of multimineral complex toothpaste; $\delta_{2}\left(S_{2} / S_{3}\right)-30 \mathrm{~min}$ after the use of multimineral complex toothpaste; $\delta_{3}\left(S^{\prime}{ }_{2} / S^{\prime}{ }_{3}\right)$ - use of calcium glycerophosphate tablets. $S_{2}, S^{\prime}{ }_{2}$ - the integral area of vibration bands for $\mathrm{C}=\mathrm{O}$ and $\mathrm{CH}_{2} / \mathrm{CH}_{3}$ bonds, localised in the range of $1430-1400 \mathrm{~cm}^{-1}, \mathrm{~S}_{3}, \mathrm{~S}^{\prime}{ }_{3}-$ the integral area of phosphates in the IR spectra (spectral regions at 900$1200 \mathrm{~cm}^{-1}$ and $730-770 \mathrm{~cm}^{-1}$ ). 
Table 3. Calculations of sampling-averaged relative changes in mineral-organic and carbon-phosphate ratios between the mineral and organic components in the mixed saliva in comparison to the reference sample at the different stages of the study

\begin{tabular}{|c|c|c|}
\hline The stages of the study/types of preventive measures & AvRC in $M / O$ ratio, $\%$ & AvRC in $\mathrm{C} / \mathrm{Ph}$ ratio, $\%$ \\
\hline \multicolumn{3}{|l|}{ Experiment №1 } \\
\hline $5 \mathrm{~min}$ after the use of $\mathrm{m}-\mathrm{m}$ complex toothpaste (ex. preventive measure) & $+69.8 \pm 2.1, p=0.032$ & $-47.8 \pm 1.9, p=0.025$ \\
\hline 30 min after the use of $\mathrm{m}-\mathrm{m}$ complex toothpaste (ex. preventive measure) & $-3.1 \pm 1.4, p>0.05$ & $+1.1 \pm 1.6, p>0.05$ \\
\hline use of CaGP tablets (end. preventive measure) & $+9.7 \pm 2.0, p=0.015$ & $-50.6 \pm 1.9, p=0.011$ \\
\hline \multicolumn{3}{|l|}{ Experiment № 2} \\
\hline $5 \mathrm{~min}$ after the use of $\mathrm{m}-\mathrm{m}$ complex toothpaste + thorough oral rinsing (ex. preventive measure ) & $+7.1 \pm 2.2, p=0.029$ & $-9.3 \pm 2.7, p=0.033$ \\
\hline $30 \mathrm{~min}$ after the use of $\mathrm{m}-\mathrm{m}$ complex toothpaste + thorough oral rinsing (ex. preventive measure ) & $-1.7 \pm 1.9, p>0.05$ & $-2.0 \pm 1.7, p>0.05$ \\
\hline On the fourth day after taking the CaGP tablets + thorough oral rinsing (end. preventive measure) & $+11.7 \pm 1.8, p=0.017$ & $-53.7 \pm 1.4, p=0.009$ \\
\hline
\end{tabular}

The data are presented as mean with standard deviation - $\mathrm{M} \pm \mathrm{SD}$.

AvRC, averaged relative change; $\mathrm{M} / \mathrm{O}$ ratio, mineral-organic ratio; $\mathrm{C} / \mathrm{Ph}$ ratio, carbon-phosphate ratio; m-m, multi-mineral; ex., exogenous; end., endogenous; CaGP, calcium glycerophosphate.

As indicated by the results from the first stage of the study (see Figures 6 and 7), the use of multi-mineral complex toothpaste results in a considerable increase in the mineral-organic ratio and a decrease in the carbon-phosphate ratio, suggesting that the exogenous source can considerably increase the mixed saliva phosphate content $\delta_{1}\left(S_{3} / S_{1}\right)$ and $\delta_{1}\left(S_{2} / S_{3}\right)$. However, this effect is short-term as the values returned to those observed before toothpaste use 30 minutes after brushing $\delta_{2}\left(S_{3} / S_{1}\right)$ and $\delta_{2}\left(S_{2} / S_{3}\right)$ (analysis demonstrated almost total absence of statistically valuable difference for the level of $p<0.05$ ).

Furthermore, thorough oral rinsing directly after brushing and 30 minutes later completely nullified the positive effect of the multi-mineral toothpaste directed at changing the organic-mineral balance of the mixed saliva $\delta_{2}\left(S_{3} / S_{1}\right)$ and $\delta_{2}\left(S_{2} / S_{3}\right)$ (Figures $6,7-$ columns marked oral rinsing). In both cases, a negative relative change of the organic-mineral ratio as compared with the reference sample was observed, with no statistical significant difference, thus, there was a washing-out of the mineral groups and complexes remaining in the oral cavity after the application of the toothpaste (Table 3). Nonetheless, the main purpose of these complexes and mineral groups is to promote remineralisation.

Analysis of the changes in the mineral-organic and carbonphosphate ratios after the participants had taken the calcium glycerophosphate tablets for three days showed statistically significant differences $(p<0.05)$ and $9 \%$ increase in the mineralorganic ratio compared to the reference sample $\delta_{3}\left(S^{\prime}{ }_{3} / S^{\prime}{ }_{1}\right)$ and $\delta_{3}\left(S_{2}{ }_{2} / S^{\prime}{ }_{3}\right)$. Similarly, an average increase of $\sim 12 \%$ was observed in the mineral-organic ratio compared to the reference sample in the second stage of the study. This increase is statistically significant $(p<0.05)$. The relative change in mineral-organic value in the second stage as compared with the first stage is due to the use of synchrotron radiation and an IR microscope, which allows a more precise determination of the corresponding values (Figures 6).

The data shows that calcium glycerophosphate tablets can change the organic-mineral balance in mixed saliva, increasing the content of mineral groups and complexes. Note that the content of endogenous, biologically accessible phosphate groups and complexes in the mixed saliva, according to our data, exceeds by approximately $12 \%$ that of the mixed saliva before the use of the prevention agents (in the reference (check) sample). It is also important to point out that just in this case a long-term effect of the mineral groups obtained by an endogenous way can be achieved.
Due to the multi-stage character of the ion exchange, the mineral groups and complexes (phosphates) should be retained for a long time within the oral cavity and should be in contact with the dental enamel $[1,6,48-50]$. As shown, this could be realised only under an endogenous supply of the ions [34, 35, 51]. The concentration of the ions in the mixed saliva ought to exceed the concentration in the hydrate layer of enamel in order to provide an efficient process of diffusion from the surface of enamel $[1,14]$.

It is well known that excessive levels of calcium and phosphates in mixed saliva result in a rapid deposition of calcium phosphates in the form of mineral phases on the surface of enamel, which hinders normal remineralisation [6]. A short-term increase in the concentration over the standard values stipulates the deposition and formation of foreign calcium phosphates resulting in the limited permeability of substances through the biofilm, the origin of dental deposit, and enhanced enamel solubility. Therefore, we believe that the identified effect of the long-term presence of the necessary groups and complexes during the use of both endo- and exogenous prevention methods creates the necessary conditions for the standard organic and mineral exchange in the oral cavity.

The use of endogenous and exogenous methods of caries prevention induces changes in the mineral-organic and carbonphosphate ratios within human mixed saliva. However, the exogenous method only provides a short-term effect. Moreover, a thorough oral rinsing after brushing eliminates the beneficial effects directed at saturating the mixed saliva with ions, mineral complexes and groups (phosphates). On the contrary, the use of calcium glycerophosphate tablets in combination with exogenous prevention allows long-term saturation of the mixed saliva with mineral groups and complexes of phosphates, i.e. an average increase of $12 \%$ in their content in the mixed saliva.

\section{Conclusion}

Changes in the molecular composition of mixed saliva when using an exogenous method of caries prevention only provides a short-term effect, continuing for the first 30 minutes after the preceding prevention. Nonetheless, the use of calcium glycerophosphate tablets in combination with brushing (a combination of endogenous and exogenous prevention methods) leads to the long-term presence of high concentrations of ions, mineral complexes and groups (phosphates) in the oral fluid. 


\section{Acknowledgements}

The part of this research was undertaken with The Infrared Microspectroscopy (IRM) beamline at the Australian Synchrotron (Victoria, Australia).

\section{Funding}

This work was supported by the grant of Russian Science Foundation, grant number 16-15-00003.

\section{Availability of data and materials}

All data collected is available by request.

\section{Conflict of interests}

The authors declare no conflict of interests.

\section{Ethics approval and consent to participate}

All patients whose data were used within the created survey had signed institutional consent for the participation research. All persons who participated in the survey signed written consent. Voronezh State University Ethics Committee approved this study (approval number 001.066-2015). All procedures performed in studies involving human participants were in accordance with the ethical standards of the institutional and national research committee and with the 1964 Helsinki declaration and its later amendments or comparable ethical standards.

\section{References}

1. García-Godoy F, Hicks MJ. Maintaining the integrity of the enamel surface: The role of dental biofilm, saliva and preventive agents in enamel demineralization and remineralization. J Am Dent Assoc 2008; 139: 25S-34S. https://dx.doi.org/10.14219/jada.archive.2008.0352.

2. Pretty IA, Ellwood RP. The caries continuum: opportunities to detect, treat and monitor the re-mineralization of early caries lesions. J Dent 2013; 41: S12-S21. https://dx.doi.org/10.1016/j.jdent.2010.04.003.

3. Agrawal N, Shashikiran ND, Singla S, Ravi KS, Kulkarni VK. Effect of remineralizing agents on surface microhardness of primary and permanent teeth after erosion. J Dent Child Chic III 2015; 81(3): 117121. http://www.ncbi.nlm.nih.gov/pubmed/25514254.

4. Scott DA, Renaud DE, Krishnasamy S, Meriç P, Buduneli N, Cetinkalp S, Liu K-Z. Diabetes-related molecular signatures in infrared spectra of human saliva. Diabetol Metab Syndr 2010; 2: 48. https://dx.doi.org/10.1186/1758-5996-2-48.

5. Júnior $C$, Cesar $P$, Strixino JF, Raniero L, Júnior $C$, Cesar $P$, Strixino JF, Raniero L. Analysis of saliva by Fourier transform infrared spectroscopy for diagnosis of physiological stress in athletes. Res Biomed Eng 2015; 31(2): 116-124. https://dx.doi.org/10.1590/2446-4740.0664.

6. Andrade MRTC, Salazar SLA, Sá LFR de, Portela M, Ferreira-Pereira A, Soares RMA, et al. Role of saliva in the caries experience and calculus formation of young patients undergoing hemodialysis. Clin Oral Investig 2015; 19(8): 1973-1980. https://dx.doi.org/10.1007/s00784015-1441-4.

7. Bellisola G, Sorio C. Infrared spectroscopy and microscopy in cancer research and diagnosis. Am J Cancer Res 2012; 2(1): 1-21. https://www.ncbi.nlm.nih.gov/pubmed/22206042.

8. Ramsay DS, Rothen M, Scott JM, Cunha-Cruz J, Network on behalf of the NP. Tooth wear and the role of salivary measures in general practice patients. Clin Oral Investig 2014; 19(1): 85-95. https://dx.doi.org/10.1007/s00784-014-1223-4.

9. Seredin P, Goloshchapov D, Kashkarov V, Ippolitov Y, Bambery K. The investigations of changes in mineral-organic and carbon-phosphate ratios in the mixed saliva by synchrotron infrared spectroscopy. Results Phys 2016; 6: 315-321. https://dx.doi.org/10.1016/j.rinp.2016.06.005.
10. Jefferies SR. Advances in remineralization for early carious lesions: a comprehensive review. Compend Contin Educ Dent 2014; 35(4): $237-$ 243. https://www.ncbi.nlm.nih.gov/pubmed/24773249.

11. Carvalho FG de, Oliveira BF de, Carlo HL, Santos RL dos, Guenês GMT, de Castro RD. Effect of remineralizing agents on the prevention of enamel erosion: a systematic review. Braz Res Pediatr Dent Integr Clin 2014; 14(1): 55-64. https://dx.doi.org/10.4034/PBOCI.2014.141.09.

12. Featherstone JDB. Remineralization, the natural caries repair process - the need for new approaches. Adv Dent Res 2009; 21(1): 4-7. https://dx.doi.org/10.1177/0895937409335590.

13. Shellis RP, Featherstone JDB, Lussi A. Understanding the chemistry of dental erosion. Monogr Oral Sci 2014; 25: 163-179. https://dx.doi.org/10.1159/000359943.

14. Li X, Wang J, Joiner A, Chang J. The remineralisation of enamel: a review of the literature. J Dent 2014; 42: S12-S20. https://dx.doi.org/10.1016/S0300-5712(14)50003-6.

15. Memarpour M, Soltanimehr E, Sattarahmady N. Efficacy of calciumand fluoride-containing materials for the remineralization of primary teeth with early enamel lesion. Microsc Res Tech 2015; 78(9): 801806. https://dx.doi.org/10.1002/jemt.22543.

16. Zhang $X$, Li $Y$, Sun $X$, Kishen $A$, Deng $X$, Yang $X$, et al. Biomimetic remineralization of demineralized enamel with nano-complexes of phosphorylated chitosan and amorphous calcium phosphate. J Mater Sci Mater Med 2014; 25(12): 2619-2628. https://dx.doi.org/10.1007/s10856-014-5285-2.

17. Weir MD, Chow LC, Xu HHK. Remineralization of demineralized enamel via calcium phosphate nanocomposite. J Dent Res 2012; 91(10): 979984. https://dx.doi.org/10.1177/0022034512458288.

18. Oliveira GMS, Ritter AV, Heymann HO, Swift Jr. E, Donovan T, Brock G, Wright T. Remineralization effect of CPP-ACP and fluoride for white spot lesions in vitro. J Dent 2014; 42(12): 1592-1602. https://dx.doi.org/10.1016/i.jdent.2014.09.004.

19. Rirattanapong $\mathrm{P}$, Vongsavan $\mathrm{K}$, Tepvichaisillapakul M. Effect of five different dental products on surface hardness of enamel exposed to chlorinated water in vitro. Southeast Asian J Trop Med Public Health 2011; 42(5): 12931298. https://www.ncbi.nlm.nih.gov/pubmed/22299456.

20. Sathe N, Chakradhar Raju RVS, Chandrasekhar V. Effect of three different remineralizing agents on enamel caries formation--an in vitro study. Kathmandu Univ Med J KUMJ 2014; 12(45): 16-20. https://www.ncbi.nlm.nih.gov/pubmed/25219988.

21. Danelon M, Pessan JP, Neto FNS, de Camargo ER, Delbem ACB. Effect of toothpaste with nano-sized trimetaphosphate on dental caries: In situ study. J Dent 2015; 43(7): 806-813. https://dx.doi.org/10.1016/j.jdent.2015.04.010.

22. Chen H-P, Chang C-H, Liu J-K, Chuang S-F, Yang J-Y. Effect of fluoride containing bleaching agents on enamel surface properties. J Dent 2008; 36(9): 718-725. https://dx.doi.org/10.1016/j.jdent.2008.05.003.

23. Zhang M, He LB, Exterkate RM, Cheng L, Li JY, Ten Cate JM, et al Biofilm layers affect the treatment outcomes of $\mathrm{NaF}$ and Nanohydroxyapatite. J Dent Res 2015; 94(4): 602-607. https://dx.doi.org/10.1177/0022034514565644.

24. Rios D, Honório HM, Magalhães AC, Buzalaf MA, Palma-Dibb RG, Machado MA, da Silva SM. Influence of toothbrushing on enamel softening and abrasive wear of eroded bovine enamel: an in situ study. Braz Oral Res 2006; 20(2): 148-154. https://dx.doi.org/10.1590/S1806-83242006000200011.

25. Chambers C, Stewart S, Su B, Sandy J, Ireland A. Prevention and treatment of demineralisation during fixed appliance therapy: a review of current methods and future applications. Br Dent J 2013; 215(10): 505-511. https://dx.doi.org/10.1038/sj.bdj.2013.1094.

26. Antunes A, de Rossi W, Zezell DM. Spectroscopic alterations on enamel and dentin after nanosecond Nd:YAG laser irradiation. Spectrochim Acta A Mol Biomol Spectrosc 2006; 64(5): 1142-1146. https://dx.doi.org/10.1016/j.saa.2005.11.036. 
27. Contreras-Bulnes R, Fernando O, Emma L, Jos R, Centeno-Pedraz C. Structural changes on human dental enamel treated with $\mathrm{Er}: \mathrm{YAG}, \mathrm{CO}_{2}$ lasers and remineralizing solution: EDS Analysis. In: Oral Health Care Prosthodontics, Periodontology, Biology, Research and Systemic Conditions. M.S. Virdi, ed. InTech; 2012. https://dx.doi.org/10.5772/28867.

28. Suetenkov DY, Petrova AP, Kharitonova TL. Photo activated disinfection efficiency of low-intensity laser and comprehensive prevention of caries and gingivitis in adolescents using bracket system. J Innov Opt Health Sci 2015; 8(3): 1541002. https://dx.doi.org/10.1142/S1793545815410023.

29. Lynch RJM, Smith SR. Remineralization agents - new and effective or just marketing hype? Adv Dent Res 2012; 24(2): 63-67. https://dx.doi.org/10.1177/0022034512454295.

30. Kalra D, Kalra R, Kini $P$, Allama Prabhu C. Nonfluoride remineralization: An evidence-based review of contemporary technologies. J Dent Allied Sci. 2014;3(1):24. https://dx.doi.org/10.4103/2277-4696.156525.

31. Mielczarek A, Michalik J. The effect of nano-hydroxyapatite toothpaste on enamel surface remineralization. An in vitro study. Am J Dent 2014; 27(6): 287-290. https://www.ncbi.nlm.nih.gov/pubmed/25707080.

32. Lynch RJM. Calcium glycerophosphate and caries: a review of the literature. Int Dent J 2004; 54(5 Suppl 1): 310-314. https://www.ncbi.nlm.nih.gov/pubmed/15509082.

33. Kligerman AE. Methods for improving healing of an oral lesion using a glycerophosphate salt. US20100305071 A1, 2010. http://www.google.ch/patents/US20100305071.

34. Damle SG, Deoyani D, Bhattal H, Yadav R, Lomba A. Comparative efficacy of dentifrice containing sodium monofluorophosphate + calcium glycerophosphate and non-fluoridated dentifrice: a randomized, double-blind, prospective study. Dent Res J 2012; 9(1): 68-73. https://dx.doi.org/10.4103/1735-3327.92948.

35. Barbosa CS, Montagnolli LG, Kato MT, Sampaio FC, Buzalaf MAR. Calcium glycerophosphate supplemented to soft drinks reduces bovine enamel erosion. J Appl Oral Sci 2012; 20(4): 410-413. https://dx.doi.org/10.1590/S1678-77572012000400004.

36. Hans KM-C, Muller S, Sigrist MW. Infrared spectroscopic determination of drugs in saliva. Conf 12th Eur Quantum Electron Conf 2011: 1-1. https://dx.doi.org/10.1109/CLEOE.2011.5943085.

37. Baker MJ, Trevisan J, Bassan P, Bhargava R, Butler HJ, Dorling KM, et al. Using Fourier transform IR spectroscopy to analyze biological materials. Nat Protoc 2014; 9(8): 1771-1791. https://dx.doi.org/10.1038/nprot.2014.110.

38. Orphanou $\mathrm{C}-\mathrm{M}$. The detection and discrimination of human body fluids using ATR FT-IR spectroscopy. Forensic Sci Int 2015; 252: e10-e16. https://dx.doi.org/10.1016/j.forsciint.2015.04.020.

39. Petibois C, Gionnet K, Gonçalves M, Perromat A, Moenner M, Déléris G. Analytical performances of FT-IR spectrometry and imaging for concentration measurements within biological fluids, cells, and tissues. Analyst 2006; 131(5): 640-647. https://dx.doi.org/10.1039/B518076G.

40. Elkins KM. Rapid Presumptive "Fingerprinting" of Body Fluids and Materials by ATR FT-IR Spectroscopy. J Forensic Sci 2011; 56(6): 15801587. https://dx.doi.org/10.1111/i.1556-4029.2011.01870.x.

41. Badea I, Crisan M, Fetea F, Socaciu C. Characterization of resting versus stimulated saliva fingerprints using middle-infrared spectroscopy assisted by principal component analysis. Romanian Biotechnol Lett 2014; 19(6): 9817-9827.

42. Khaustova S, Shkurnikov M, Tonevitsky E, Artyushenko V, Tonevitsky A. Noninvasive biochemical monitoring of physiological stress by Fourier transform infrared saliva spectroscopy. Analyst 2010; 135(12): 31833192. https://dx.doi.org/10.1039/COAN00529K.

43. Ren Z, Do LD, Bechkoff G, Mebarek S, Keloglu N, Ahamada S, et al. Direct determination of phosphatase activity from physiological substrates in cells. PLOS ONE 2015; 10(3): e0120087. https://dx.doi.org/10.1371/journal.pone.0120087.
44. Kong J, Yu S. Fourier transform infrared spectroscopic analysis of protein secondary structures. Acta Biochim Biophys Sin 2007; 39(8): 549-559. https://www.ncbi.nlm.nih.gov/pubmed/17687489.

45. Berzina-Cimdina L, Borodajenko N. Research of Calcium phosphates using fourier transform infrared spectroscopy. In: Infrared Spectroscopy - Materials Science, Engineering and Technology. T. Theophile, ed. InTech, 2012: p. 123-148. https://dx.doi.org/10.5772/36942.

46. Seredin P, Kashkarov V, Lukin A, Ippolitov $Y$, Julian R, Doyle S. Local study of fissure caries by Fourier transform infrared microscopy and $X$ ray diffraction using synchrotron radiation. J Synchrotron Radiat 2013; 20(5): 705-710. https://dx.doi.org/10.1107/S0909049513019444.

47. Chiappin S, Antonelli G, Gatti R, De Palo EF. Saliva specimen: a new laboratory tool for diagnostic and basic investigation. Clin Chim Acta 2007; 383(1-2): 30-40. https://dx.doi.org/10.1016/j.cca.2007.04.011.

48. Hara AT, Zero DT. The potential of saliva in protecting against dental erosion. Monogr Oral Sci 2014; 25: 197-205. https://dx.doi.org/10.1159/000360372.

49. Fidalgo TKS, Freitas-Fernandes LB, Almeida FCL, Valente AP, Souza IPR. Longitudinal evaluation of salivary profile from children with dental caries before and after treatment. Metabolomics 2014; 11(3): 583593. https://dx.doi.org/10.1007/s11306-014-0717-z.

50. Wang X, Mihailova B, Klocke A, Heidrich S, Bismayer U. Effect of artificial saliva on the apatite structure of eroded enamel. Int J Spectrosc 2011; 2011: e236496. https://dx.doi.org/10.1155/2011/236496.

51. Tanaka T, Kobayashi T, Takii H, Kamasaka H, Ohta N, Matsuo T, et al. Optimization of calcium concentration of saliva with phosphoryl oligosaccharides of calcium (POs-Ca) for enamel remineralization in vitro. Arch Oral Biol 2013; 58(2): 174-180. https://dx.doi.org/10.1016/i.archoralbio.2012.07.004.

\section{Authors:}

Pavel V. Seredin - PhD, Associate Professor, Department of Solid State Physics and Nanostructures, Voronezh State University, Voronezh, Russia. http://orcid.org/0000-0002-6724-0063.

Dmitry L. Goloshchapov - PhD, Researcher, Department of Solid State Physics and Nanostructures, Voronezh State University, Voronezh, Russia. http://orcid.org/0000-0002-1400-2870.

Yuri A. Ippolitov - MD, PhD, Head of Pediatric Dentistry with Orthodontia, Voronezh State Medical University n.a. N.N. Burdenko, Voronezh, Russia. http://orcid.org/0000-0001-9922-137X.

Edvard S. Kalivradzhiyan - MD, DSc, Professor, Department of Orthopaedic Dentistry, Voronezh State Medical University n.a. N.N. Burdenko, Voronezh, Russia. http://orcid.org/0000-0001-5874-8327. 